\title{
THE ROLE OF THE PROPOLIS ON THE PREVALENCE OF DESTRUCTIVE PERIODONTAL PATHOGEN IN AGGRESSIVE PERIODONTITIS
}

\author{
Mohamed Mostafa El-Shennawi * and Mansour Mohammed Ali Asiri **
}

\begin{abstract}
The present study was carried out on eighteen patients having aggressive periodontitis (exhibiting at least three single-rooted teeth with periodontal pocket depth $\geq 5 \mathrm{~mm}$ ) divided into 3 groups, each group was six patients. It was noticed that, surgical treatment of aggressive periodontitis was shown to be more effective than conventional scaling and root planing procedures alone. Additionally, the use of antibiotic agent as adjunctive to surgical treatment was proven to be beneficial in the reduction or elimination of bacterial load in the tissues invaded the periodontopathogens. Among the known natural antibacterial agent, is the Propolis (bee glue) which also has many other pharmacological properties such as anti-inflammatory, and immunemodulatory properties. Therefore, the purpose of this study was to clinically evaluate the effect of Propolis in the treatment of aggressive periodontitis, and microbiologically test its effect against Actinobacillus actinomycetemcomitans. Clinical evaluation was performed using plaque, bleeding indices and PPD and CAL at baseline, six weeks and three months after surgical treatment for both groups (II), (III). The results revealed that there was statistical significant improvement in all clinical parameters for all patients after different methods of treatment. Microbiological, positive culture results were revealed in all samples collected before treatment, on the other hand, negative culture results were revealed in all samples collected six weeks after surgical treatment for both groups (II) \& (III), as well as in all samples of group (III) collected after three months after treatment. Through this study we can concluded that systemic administration of propolis with SRP and periodontal flap surgery showed clinical and microbiological improvement reduction results in patients with aggressive periodontitis.
\end{abstract}

* Professor of Periodontology; Faculty of Dentistry, King Abdulaziz University (K.S.A). Kingdum of Saudia Arebia. Professor Of Periodontology; Faculty of Dentistry, Mansoura University. Egypt

** Consultant of Periodontology; Dental Center Ohod Hospital, El-Madina El Monawarah. Kingdum of Saudia Arebia. 


\section{INTRODUCTION}

Periodontitis is an infectious condition initiated by microbial plaque, which accumulates on the tooth surfaces at the gingival margin and induces an inflammatory reaction (Janson) ${ }^{(1)}$. The function of the inflammatory process is to protect the host; however, this process may also contributes to destruction of the supporting connective tissue and alveolar bone resulting in pocket formation, gingival recession, and finally teeth loss (Calas-Bennasar et al) ${ }^{(2)}$.

Aggressive periodontitis is a rapidly progressive disease that affects otherwise healthy individuals, and has multifactorial etiology of the disease, may be related to immunologic defects in the function of polymorphonuclear leukocytes (PMNLs) (Meng et al) ${ }^{(3)}$, genetic variations in host response (Nibali et al) ${ }^{(4)}$, and environmental factors such as smoking and inappropriate nutrition are associated with high levels oxidatives stress, (Tomofuji et al) ${ }^{(5)}$.

The microbiota responsible for aggressive periodontitis is complex, and composed mainly of gram-ve bacteria; such as Porphyromonas gingivalis, Prevotella intermedia, Fusobacterium nucleatum, tannerella forsythia, Compylobacter rectus, treponema denticola, Capnocytophaga sputigena and most predominantly Actinobacillus actinomycetemcomitans (recently known as Aggregatibacter actinomycetemcomitans) (Faveri et al). ${ }^{(6,7)}$

A. actinomycetemcomitans is considered a key microorganism in the aggressive periodontitis cases (Faveri et al) ${ }^{(7)}$ and produces a number of virulence factors that may contribute to the pathogenesis of this disease (Ximenez-Fyvie et al) ${ }^{(8)}$, they adhere and invade oral epithelial cells and grow intracellularly, thus escaping attempts at eradication by root debridement (Andrian et al) ${ }^{(9)}$.

The effect of aggressive periodontitis reaches beyond the oral cavity. A. actinomycetemcomitanus translocates from the oral cavity into the circulatory system to cause extraoral infections in various body sites; such as, thyroid gland, brain and urinary tract (Henderson et al) $^{(10)}$. A. actinomycetemcomitanus has an enhanced capacity to produce endocardial infections (Patural etal) ${ }^{(11)}$.

Non-surgical periodontal therapy alone (scaling and root planning) are effective in chronic periodontitis, but are less effective in patients with aggressive periodontitis (Cairo do Amaral et al) (12). Therefore, antimicrobials usage as adjunct to periodontal therapy improves the therapeutic outcome and eliminates the periodontopathogens (Xajigeorgiou et al) $^{(13)}$.

Many chemotherapeutic agents were used as a trail through researches for control the aggressive periodontitis, (such as tetracycline, clindamycin, amoxicillin with or without metronidazole).

Propolis is a natural balm, (Bee Glue), sticky, resinous and waxy substance collected by honeybees from various plant sources such as buds and exudates, and it is widely employed in flok medicine (Cairo do Amaral et al) ${ }^{(12)}$.

Propolis recently has gained popularity as a health drink and food to improve health and prevent diseases such as inflammation, heart disease, diabetes and even cancer(Castaldo and Capasso) ${ }^{(14)}$.

Propolis is available in the form of capsules, mouthwashes, lozenges and creams, it's chemical composition is composite of $30 \%$ bees was, $50 \%$ resin and vegetable balsam, $10 \%$ essential and aromatic oils, $5 \%$ pollen, and $5 \%$ other substances like aluminum, calcium, and organic debris (Bankova et a) ${ }^{(15)}$.

The most important pharmacologically active constituents in the Propolis are flavonoids which have antioxidant (kalogeropoulos et al) ${ }^{(16)}$, antiinflammatory (Bankova et al) $)^{(15)}$, and antimicrobial immunomodulatory, anticancer and anesthetic properties (Castaldo and Capasso) ${ }^{(14)}$. 
The antibacterial effect of propolis involves several mechanisms such as; inhibition of protein synthesis, partial bacteriolysis, and disorganization of the cytoplasm, the cytoplasmatic membrane and the cell wall, also propolis was found to affect the bacterial mobility and enzyme activity and stimulates the antibodies production (Sforcin et al) ${ }^{(17)}$. Cushnie and $\mathrm{lamb}^{(18)}$ found that, the flavonoids of propolis has antibacterial mechanism of action includes inhibition of the nucleic acid synthesis, cytoplasmic membrane function and energy metabolism.

In addition, Propolis has an antibacterial activity against several periodontopathogenic bacteria; such as P.gingivalis (Koru et al) ${ }^{(19)}$, P. intermedia (Boyanova et al) $)^{(20)}$, T. denticola (Koo et al) ${ }^{(21)}$ and A. actinomycetemcomitans (Gomes et al) ${ }^{(22)}$. Nehal N.S et $\mathrm{al}^{(23)}$ found that propolis has adjuvant in the treatment of chronic periodontitis, also Coutinho et $\mathrm{al}^{(24)}$ \& Al-Dany A. et al ${ }^{(25)}$ said that propolis has effect in preventing gingivitis and dental caries in patients undergoing orthodontic treatment. Therefore, Propolis appears to be a promising adjunctive modality in the treatment of aggressive periodontitis.

\section{AIM OF THE STUDY}

The aims of the present study are:-

- Compare the clinical improvement of aggressive periodontitis after scaling and root planing \& periodobntal surgery with and without propolis.

- Idnetificate of A. actinomycetemcomitanus in study patients after treatment and evaluate the antibacterial activity of the propolis on the periodontal pathogens in aggressive periodontitis.

\section{PATIENTS AND METHODS}

The present study was carried out on 18 patients ( 11 female and 7 males, aged $24-38$ years) diagnosed with aggressive periodontitis, exhibiting at least three single-rooted teeth with periodontal pocket depth $\geq 5 \mathrm{~mm}$, who reported to the Department of Periodontics, Ohod Dental Center, Ohad Hospital, El- Madinah El Menawarah Kingdum of Saudia Arebia,were selected for the study.

The selected patients were found free from any systemic disease, and not receiving any medications three months prior to the study. Furthering, none of them had previous periodontal treatment including scaling/root planing and periodontal surgery in the last six months, also smoker and pregnant patients were excluded.

Study design: The selected cases were divided into three groups of six patients as the following:

\section{Group I}

The patients had undergone phase (I) periodontal therapy (scaling and root planing) without periodontal surgery or the use of Propolis.

\section{Group II}

The patients had undergone phase (I) \& (II) periodontal surgery (surgical treatment) without the use of Propolis.

\section{Group III}

The patients had undergone the same steps as group (II), (SRP \& Periodontal surgery), with the use of Propolis.

The periodontal surgery was Modified Widman Flap technique at the chosen segment (PPD should not be less than $5 \mathrm{~mm}$ ) for the patients of group (II) \& (III).

Propolis was supplied as capsules $178 \mathrm{mg}$ (made by Arkopharma, Spain), where Patients of study group (III) instructed to take propolis one day before surgery and continuo three times daily for 10 days after surgery (Samet et al) ${ }^{(26)}$. 


\section{Clinical evaluation}

Clinical evaluation was performed using the following clinical parameters:

1- Plaque index (Loe H.(1967) $)^{(27)}$

2- Bleeding index (Loe H., Silness J.(1963) $)^{(28)}$

3- Pocket depth \& Clinical attachment loss (Carranza et al 2006) ${ }^{(29)}$

All the clinical collected samples were obtained subsequently at the time of starting the study, six weeks and three months after treatment (Xajigeorgiou et al) $^{(13)}$.

\section{Microbiological laboratory steps:}

I- Materials used for sample collection and transports were:

Sterile medium-sized endodontic paper points, Anaerobic Ringer's solution.

II- Materials used for A. actinomycetemcomitans isolation:

TSBV agar (tryptic Soy-Serum-Bacitracin-Vancomycin agar), the plates were stored aerobically at $5^{\circ} \mathrm{C}$ and used within 4 days of preparation (Slots) $^{(30)}$.
III- Materials used for identification of A. actinomycetemcomitans:

1- Gram stain.

2- Biochemical reaction:

a. Oxidase reaction: Oxidase detection strips. (this test was used for detection of bacterial cytochrome oxidase enzyme).

b. Catalase reaction: $\mathrm{H}_{2} \mathrm{O}_{2}$ solution (10 vol). (this test demonstrated the prescence of catalase enzyme that catalyses the release of oxygen from hydrogen peroxide $\left(\mathrm{H}_{2} \mathrm{O}_{2}\right)$.

c. Sugar fermentation test: glucose, maltose, lactose and distilled water. (Cruickshank et al) ${ }^{(31)}$.

\section{Statistical Analysis}

Statistical analysis of the obtained data was done by using excel program and SPSS program (Statistical Package for Social Science) version 10 .

N.B: $\mathrm{P}$ is significant if $<$ or $=0.05$ at confidence interval $95 \%$.

TABLE (1) was shown the pre-operative clinical findings of the periodontal characters for selected patients of the three groups.

\begin{tabular}{|c|c|c|c|c|c|c|l|}
\hline Group & Sex & Patients & $\begin{array}{c}\text { Plaque \& } \\
\text { Calculus Deposits }\end{array}$ & B.I & $\begin{array}{c}\text { Mean of } \\
\text { PPD }\end{array}$ & $\begin{array}{c}\text { Mean of } \\
\text { CAL }\end{array}$ & \multicolumn{1}{|c|}{ Pt.'s complaints } \\
\hline \multirow{2}{*}{ I } & F & 3 & Moderate & Moderate & $6.6 \mathrm{~mm}$ & 6.8 & $\begin{array}{l}\text { Feeling of Teeth mobile, Bleeding on } \\
\text { probing \& Food impaction }\end{array}$ \\
\cline { 2 - 8 } & $\mathrm{M}$ & 3 & Moderate & Moderate & $5.7 \mathrm{~mm}$ & 5.9 & Itching sensation \& Food impaction \\
\hline \multirow{2}{*}{ II } & $\mathrm{F}$ & 4 & Severe & Severe & $6.4 \mathrm{~mm}$ & 8.1 & $\begin{array}{l}\text { Bleeding on probing \& } \\
\text { Food impaction }\end{array}$ \\
\cline { 2 - 8 } & $\mathrm{M}$ & 2 & Moderate & Moderate & $7.10 \mathrm{~mm}$ & 7.6 & Itching sensation \& Food impaction \\
\hline \multirow{2}{*}{ III } & $\mathrm{F}$ & 4 & Severe & Moderate & $6.8 \mathrm{~mm}$ & 7.8 & $\begin{array}{l}\text { Feeling of Teeth mobile \&Bleeding } \\
\text { on brushing with Food impaction }\end{array}$ \\
\cline { 2 - 8 } & $\mathrm{M}$ & 2 & Moderate & Moderate & $5.9 \mathrm{~mm}$ & 7.4 & Teeth mobile \& Food impaction \\
\hline
\end{tabular}




\section{RESULTS}

A total eighteen patients (11 females and 7 males) were followed the technique of treatment according to each group.

\section{Statistical analysis of the clinical parameters:}

The mean values and standard deviation of the clinical parameters at the baseline and three months after treatment of group (I) were shown in table(2) using paired sample t-test, there was a high statistical significant improvement in the clinical parameters after three months of treatment when compared to the baseline values at $\mathrm{P}<0.001$.

TABLE (II): Shown mean value of the clinical parameters at the base line and three months after treatment in group (1)

\begin{tabular}{|c|c|c|c|}
\hline $\begin{array}{c}\text { Clinical } \\
\text { parameters }\end{array}$ & Base line & $\begin{array}{c}\text { After 3 } \\
\text { months }\end{array}$ & P-value \\
\hline Plaque index & $1.45 \pm 0.33$ & $0.21 \pm 0.31$ & $<0.001^{* *}$ \\
\hline Bleeding index & $1.20 \pm 0.31$ & $0.15 \pm 0.11$ & $<0.001^{* *}$ \\
\hline PPD & $2.45 \pm 0.30$ & $1.11 \pm 0.13$ & $<0.001^{* *}$ \\
\hline CAL & $2.83 \pm 0.40$ & $1.50 \pm 0.42$ & $<0.001^{* *}$ \\
\hline
\end{tabular}

** highly significant at $P<0.001$

The mean values and standard deviation of the clinical parameters at the baseline and three months after treatment of group (II) were shown in table(3) using paired sample t-test, there was a high statistical significant improvement in the clinical parameter after three months of treatment was observed in both the plaque and bleeding indices at $\mathrm{P}=0.005,0.002$ respectively. Moreover, a high statistical significant improvement in both PPD and CAL was observed after three months of treatment when compared to the baseline values $\mathrm{P}<0.001$.
TABLE (III): Shown the mean value of the clinical parameters at the base line and three months after treatment in group (11)

\begin{tabular}{|c|c|c|c|}
\hline $\begin{array}{c}\text { Clinical } \\
\text { parameters }\end{array}$ & Base line & $\begin{array}{c}\text { After 3 } \\
\text { months }\end{array}$ & P-value \\
\hline Plaque index & $0.92 \pm 0.51$ & $0.12 \pm 0.14$ & $<0.005^{*}$ \\
\hline Bleeding index & $0.80 \pm 0.44$ & $0.08 \pm 0.06$ & $<0.002^{*}$ \\
\hline PPD & $2.53 \pm 0.55$ & $1.23 \pm 0.14$ & $<0.001 * *$ \\
\hline CAL & $3.21 \pm 0.51$ & $1.93 \pm 0.39$ & $<0.001 * *$ \\
\hline
\end{tabular}

*Significant at $P \leq 0.05$

** highly significant at $P<0.001$

The mean values and standard deviation of the clinical parameters at the baseline and three months after treatment of group (III) were shown in table(4) using paired sample t-test, all subjects showed a high statistical significant improvement in the clinical parameters after three months of treatment when compared to the baseline values at $\mathrm{P}<0.001$.

TABLE (IV): Shown the mean value of the clinical parameters at the base line and three months after treatment in group (111)

\begin{tabular}{|c|c|c|c|}
\hline $\begin{array}{c}\text { Clinical } \\
\text { parameters }\end{array}$ & Base line & $\begin{array}{c}\text { After 3 } \\
\text { months }\end{array}$ & P-value \\
\hline Plaque index & $1.06 \pm 0.33$ & $0.16 \pm 0.01$ & $<0.001^{* *}$ \\
\hline Bleeding index & $0.88 \pm 0.21$ & $0.11 \pm 0.06$ & $<0.001^{* *}$ \\
\hline PPD & $2.81 \pm 0.68$ & $1.13 \pm 0.01$ & $<0.001^{* *}$ \\
\hline CAL & $3.08 \pm 0.79$ & $1.38 \pm 0.24$ & $<0.001^{* *}$ \\
\hline
\end{tabular}

** highly significant at $P<0.001$

It was noticed that there was marked improvement in the periodontal status for all patients in the three groups. Moreover, clinical examination three months post-operatively revealed considerable improvement in the symptoms of the disease in terms of gingival bleeding, teeth mobility and food impaction. 


\section{Comparison between the three groups}

Inter-group comparison of the plaque index at the baseline and three months after treatment was shown in table (5), Bleeding index table (6), periodontal probing depth reading table (7) and clinical attachment level recording table (8).

Through the tables the results revealed that there were no significant difference between the three groups in the plaque and bleeding indices at the baseline and after three months. Regarding the PPD and CAL, there were significant differences between the three groups after the end of the treatment.

The reduction of PPD and improvement of CAL in group (III), (in which Propolis treatment was used) was significantly greater than those in groups (I) \& (II).

\section{Bacteriological Results}

Isolation and identification of A.actionmycetemcomitans were achieved for all the patients by using of Tryptic Soy BacitracinVancomycin (TSBV) agar. The colonies of A. actionmycetemcomitans on (TSBV) agar appeared as circular, convex, translucent, glistening and it was 0.5 to $1.0 \mathrm{~mm}$ in diameter with slightly irregular edges after incubation for 3 days. The isolated colonies were confirmed by biochemical reactions such as catalase test, oxidase test and sugar fermentation for glucose, maltose and lactose. The total count of A. actinomycetemcomitans colonies were calculated from every clinical group. Table (9) showed the count of A. actinomycetemcomitans colonies in each group.

1- All selected cases were positive for A. actinomycetemcomitans at first sampling time (before starting the treatment).

2- Groups (I) \& (III) four patient's samples were positive and negative for the bacterium samples, while group (II) showed five positive and one negative bacterium samples.

TABLE (V): Inter-group comparison of Plaque index at the Baseline and three months after treatment:

\begin{tabular}{|c|c|c|c|c|c|}
\hline \multirow{2}{*}{ Time } & Groups & $\mathbf{M} \pm \mathbf{S D}$ & $\begin{array}{c}\text { Inter group } \\
\text { comparison }\end{array}$ & P-value & Significant \\
\hline \multirow{3}{*}{ Base line } & Group I & $1.43 \pm 0.35$ & I vs III & $0.03^{*}$ & Significant \\
\cline { 2 - 5 } & Group II & $0.92 \pm 0.51$ & II vs I & 0.09 & \multirow{2}{*}{ No significant difference } \\
\cline { 2 - 5 } & Group III & $1.06 \pm 0.33$ & III vs II & 0.62 & \multirow{2}{*}{ No significant difference } \\
\hline \multirow{3}{*}{ After 3 months } & Group I & $0.21 \pm 0.31$ & I vs III & 0.51 & 0.36 \\
\cline { 2 - 5 } & Group II & $0.12 \pm 0.14$ & II vs I & 0.79 & \\
\cline { 2 - 5 } & Group III & $0.16 \pm 0.01$ & III vs II & & \\
\hline
\end{tabular}

TABLE (VI): Inter-group comparison of Bleeding index at the Baseline and three months after treatment:

\begin{tabular}{|c|c|c|c|c|c|}
\hline Time & Groups & $\mathbf{M} \pm \mathbf{S D}$ & $\begin{array}{l}\text { Inter group } \\
\text { comparison }\end{array}$ & P-value & Significant \\
\hline \multirow{3}{*}{ Base line } & Group I & $1.20 \pm 0.31$ & I vs III & 0.06 & No significant difference \\
\hline & Group II & $0.85 \pm 0.21$ & II vs I & $0.05^{*}$ & Significant \\
\hline & Group III & $0.84 \pm 0.40$ & III vs II & 0.88 & No significant difference \\
\hline \multirow{3}{*}{ After 3 months } & Group I & $0.15 \pm 0.11$ & I vs III & 0.61 & \multirow{3}{*}{ No significant difference } \\
\hline & Group II & $0.11 \pm 0.06$ & II vs I & 1.00 & \\
\hline & Group III & $0.06 \pm 0.08$ & III vs II & 0.61 & \\
\hline
\end{tabular}


TABLE (VII) : Inter-group comparison of PPD readings at the Baseline and three months after treatment:

\begin{tabular}{|c|c|c|c|c|c|}
\hline \multirow{2}{*}{ Time } & Groups & M \pm SD & $\begin{array}{c}\text { Inter group } \\
\text { comparison }\end{array}$ & P-value & Significant \\
\hline \multirow{3}{*}{ Base line } & Group I & $2.45 \pm 0.30$ & I vs III & 0.57 & \multirow{2}{*}{ No significant difference } \\
\cline { 2 - 5 } & Group II & $2.53 \pm 0.55$ & II vs I & 0.09 & \\
\cline { 2 - 5 } & Group III & $2.88 \pm 0.61$ & III vs II & 0.24 & Significant \\
\hline \multirow{3}{*}{ After 3 months } & Group I & $1.11 \pm 0.13$ & I vs III & $0.05^{*}$ & No significant difference \\
\cline { 2 - 5 } & Group II & $0.24 \pm 0.13$ & II vs I & 0.79 & Significant \\
\cline { 2 - 5 } & Group III & $1.13 \pm 0.01$ & III vs II & $0.03 *$ & \\
\hline
\end{tabular}

Table (VIII): Inter-group comparison of CAL readings at the Baseline and three months after treatment:

\begin{tabular}{|c|c|c|c|c|c|}
\hline Time & Groups & $\mathrm{M} \pm \mathrm{SD}$ & $\begin{array}{l}\text { Inter group } \\
\text { comparison }\end{array}$ & P-value & Significant \\
\hline \multirow{3}{*}{ Base line } & Group I & $2.85 \pm 0.40$ & I vs III & 0.21 & \multirow{3}{*}{ No significant difference } \\
\hline & Group II & $3.2 \pm 0.51$ & II vs I & 0.39 & \\
\hline & Group III & $3.09 \pm 0.78$ & III vs II & 0.69 & \\
\hline \multirow{3}{*}{ After 3 months } & Group I & $1.50 \pm 0.42$ & I vs III & $0.04 *$ & Significant \\
\hline & Group II & $0.93 \pm 0.39$ & II vs I & 0.56 & No significant difference \\
\hline & Group III & $1.24 \pm 0.34$ & III vs II & $0.01 *$ & Significant \\
\hline
\end{tabular}

TABLE (IX): Count of A. actinomycetemcomitans colonies in each group at different sampling times.

\begin{tabular}{|c|c|c|c|c|c|}
\hline \multicolumn{2}{|c|}{ Samples/Pts } & $\begin{array}{c}1^{\text {st }} \\
\text { Before Treatment }\end{array}$ & $\begin{array}{c}2^{\text {nd }} \\
\text { After SRP }\end{array}$ & $\begin{array}{c}3^{\text {rd }} \\
\text { After surgery }\end{array}$ & $\begin{array}{c}4^{\text {th }} \\
\text { After } 3 \text { months }\end{array}$ \\
\hline Group I & $\begin{array}{l}1 \\
2 \\
3 \\
4 \\
5 \\
6\end{array}$ & $\begin{array}{l}2 \times 10^{4} \\
2 \times 10^{3} \\
2 \times 10^{4} \\
2 \times 10^{4} \\
2 \times 10^{3} \\
2 \times 10^{4}\end{array}$ & $\begin{array}{c}--- \\
1.8 \times 10^{2} \\
2 \times 10^{2} \\
1.7 \times 10^{2} \\
--- \\
1.5 \times 10^{2}\end{array}$ & $\begin{array}{l}- \\
- \\
- \\
- \\
- \\
-\end{array}$ & $\begin{array}{c}2 \times 10^{4} \\
2 \times 10^{2} \\
0 \\
2 \times 10^{3} \\
0 \\
1.8 \times 10^{2}\end{array}$ \\
\hline \multicolumn{2}{|c|}{$\mathrm{MD} \pm \mathrm{SD}$} & $\begin{array}{l}12286 \pm 9621 \\
14,000 \pm 98.4\end{array}$ & $128.57 \pm 89.52$ & 0 & $\begin{array}{c}3483 \pm 7339 \\
3730 \pm 654\end{array}$ \\
\hline \multicolumn{2}{|c|}{ Group II } & $\begin{array}{l}2 \times 10^{4} \\
2 \times 10^{4} \\
2 \times 10^{3} \\
2 \times 10^{3} \\
2 \times 10^{3} \\
2 \times 10^{3}\end{array}$ & $\begin{array}{c}1.7 \times 10^{2} \\
1.7 \times 10^{2} \\
1.5 \times 10^{2} \\
1.5 \times 10^{2} \\
--- \\
2 \times 10^{2}\end{array}$ & $\begin{array}{l}0 \\
0 \\
0 \\
0 \\
0 \\
0\end{array}$ & $\begin{array}{c}1.7 \times 10^{2} \\
1.7 \times 10^{2} \\
0 \\
0 \\
2 \times 10^{2} \\
0\end{array}$ \\
\hline \multicolumn{2}{|c|}{$\mathrm{MD} \pm \mathrm{SD}$} & $\begin{array}{l}7143 \pm 8783 \\
8000 \pm 91.3\end{array}$ & $\begin{array}{c}148.57 \pm 68.66 \\
140 \pm 70.12\end{array}$ & 0 & $77 \pm 97$ \\
\hline \multicolumn{2}{|c|}{ Group III } & $\begin{array}{l}2 \times 10^{4} \\
2 \times 10^{4} \\
2 \times 10^{3} \\
2 \times 10^{3} \\
2 \times 10^{3} \\
2 \times 10^{3}\end{array}$ & $\begin{array}{c}1.5 \times 10^{2} \\
1.7 \times 10^{2} \\
--- \\
1.8 \times 10^{2} \\
--- \\
2 \times 10^{2}\end{array}$ & $\begin{array}{l}0 \\
0 \\
0 \\
0 \\
0 \\
0\end{array}$ & $\begin{array}{l}0 \\
0 \\
0 \\
0 \\
0 \\
0\end{array}$ \\
\hline \multicolumn{2}{|c|}{$\mathrm{MD} \pm \mathrm{SD}$} & $\begin{array}{c}9714 \pm 9621 \\
11,000\end{array}$ & $\begin{array}{c}128.57 \pm 89.52 \\
116.67\end{array}$ & 0 & 0 \\
\hline
\end{tabular}


3- After six weeks of surgical treatment there was no growth of A. actinomycetemcomitans on TSBV agar for all patients in the two surgical groups (II) \& (III).

4- After three months groups(III) showed no growth of bacterium for all patients whom Propolis was used in the treatment regime, while in group (II) there were three positive (with reduction of bacterial count), and three negative growth \& in group(I) four showed positive growth and two negative bacterium growth.

\section{DISCUCCION}

Aggressive periodontitis had attracted many reports because of its increased prevalence and its rapid rate of periodontal tissues destruction in a relatively young subjects leading to edentulism early in life (Guerrero et al) ${ }^{(32)}$. Moreover, the treatment of aggressive periodontitis has always presented a challenge for clinicians, since there are no established protocols and guidelines for efficiency controlling this disease (Xajigeorgiou et al) ${ }^{(13)}$.

Haas et $\mathrm{al}^{(33)}$ suggested that systemic administered antimicrobials can enhance the effect of mechanical therapy in the treatment of aggressive periodontitis as assessed by clinical parameters. Although electron microscopic studies of the periodontium in aggressive periodontitis, patients had revealed mixed bacterial invasion of connective tissue reaching the bone surface, A. actionmycetemcomitans is considered the key microorganism in this condition (Trevilatto et al) ${ }^{(34)}$ and associated with the onset of the disease(Faveri et al) ${ }^{(7)}$.

The results was clearly evident by the insignificant difference between groups regarding the PPD and CAL at the baseline time (Table $7 \& 8$ ). In addition, no significances between the different groups considering the plaque and bleeding indices at the baseline except between group (III) \& (I) (P= 0.05 ), respectively (table $5 \& 6$ ). All patients were positive for A. actionmycetemcomitans at the time point (table 9). These could be explained by the fact that A.actionmycetemcomitans is the key pathogen in cases of aggressive periodontitis

After completing phase (1) periodontal therapy, all patients showed marked resolution of the gingival inflammation. This is owing to decrease of the bacterial load in the accumulation plaque and calculus, and also due to patient motivation and professional follow up for continuous oral hygiene care (Umeda et al) ${ }^{(35)}$ in addition, minimal reduction in PPD and minimal gain in CAL were obtained in pocket $\leq 5 \mathrm{~mm}$ depth.

The second subgingival plaque samples were collected after completion of SRP and various results were obtained (table 9). Five patient's samples; (two in group (III), one in group (II), and two in group (I); showed disappearance of A. actionmycetemcomitans. This was attributed to the accessible, shallower pocket area $(\leq 5 \mathrm{~mm})$ that allows for complete eradication to the plaque biofilm and maintenance by oral hygiene measures. These findings were in accordance with Haffajee ${ }^{(36)}$ who investigated the evaluate the effect of SRP on the subgingival microflora. Also the results showed minimal reduction in the count of (table 9) A. actionmycetemcomitans (three in groups (I) \& (III) an four in group (II)) this is attributed to the effect of mechanical disruption of plaque biofilm which from the protected environment of the pathogen (Umeda et al) ${ }^{(35)}$ Additionally, three patients samples(one in each group); showed no observable reduction in the count of A. actionmycetemcomitans. This is owing to the ability of this microorganism to adhere and invade oral epithelial cells and can even grow intracellulary, thus escaping attempts for reduction by root debridement (Andrian et al) ${ }^{(9)}$. These results were in agreement with Kleinfelder et $\mathrm{al}^{(37)}$ $\&$ Winkel et $\mathrm{al}^{(38)}$ who reported detectable levels of A. actionmycetemcomitans after conventional, mechanical treatment of periodontal infections with that bacterium. In addition Muller and 
Heinecke $^{(39)}$ reported PPD reduction and CAL gain after SRP irrespective of presence or absence of A.actionmycetemcomitans.

All cultured at the third subgingival plaque samples were collected six weeks after treatment for all the three groups revealed negative for A. actionmycetem comitans (table 9) that is because SRP and surgical procedures increase the accessibility for healing to the root surface and bony defects, making it possible to remove all irritants such as plaque, calculus and granulation tissue invaded by the pathogens from difficult and inaccessible areas (Hung and Douglass ${ }^{(40)} \&$ Kim et $\mathrm{al}^{(41)}$.

Three months after phase II periodontal therapy, there were marked reduction of gingival inflammation, marked reduction in PPD and marked CAL gain in all groups that appear clearly in table $(2,3$ \&4) when $\mathrm{P}<0.05$ or $\mathrm{P}<0.001$. There was reduction of gingival inflammation and tissue healing could be attributed to the subsequent increase in the accessibility for proper oral hygiene measures, maintenance and thoroughness of treatment procedures. Moreover, no statistical difference was observed between the different groups regarding the plaque and bleeding indices at the end of the treatment (table $5 \& 6$ ), these results were in accord with Serino et $\mathrm{al}^{(42)}$ who compared the non-surgical and surgical procedures in the treatment of aggressive periodontitis.

Interestingly, it was found that patients in the Propolis group showed more reduction in PPD and more gain in attachment than that seen in the other two groups at the end of treatment. There were statistical significant differences between group (III) and (II) in PPD (P=0.03, table 7) and CAL (P= 0,01 , table 8).

Furthering, statistical significant differences were observed between group (III) and (I) in PPD $(\mathrm{P}=0.05$, table 7) and CAL $(\mathrm{P}=0.04$, table 8$)$ after three months of treatment. These results of the present study indicated a beneficial effect of Propolis where it was in agreement with Kleinfelder et $\mathrm{al}^{(37)}$.
This could be attributed to the multiple pharmacological properties that Propolis has, especially the ant-inflammatory properties . Poroplis can inhibit the synthesis of prostaglandins, promote the phagocytic activity, stimulate the cellular immunity and augment healing effect on epithelial tissues $\mathrm{Koo}$ et $\mathrm{al}^{(21)}$. Additionally, Propolis contains elements such as iron and zinc that are important for synthesis of collagen (Marcucci) ${ }^{(43)}$. Moreover, Propolis can inhibit osteoclast maturation (Pileggi et al) ${ }^{(44)}$, thus, preventing marginal bone loss after surgery. Cairo do Amaral et $\mathrm{al}^{(12)}$ used Propolis gel, where they applied the gel once a week for five weeks, that resulted in regression of $95 \%$ of gingivitis and suppuration in all periodontal pockets with PPD reduction. Considering the patients of group (III) compliance, no adverse side effects were observed or reported in our patients who used Propolis.

On the other hand, no statistical significant differences were found between groups (II) and (I) regarding $\mathrm{PPD}(\mathrm{P}=0,79$, table 7$)$ and $\mathrm{CAL}(\mathrm{P}=0.56$, table 8 ) by completion of the study.

In respect to the fourth subgingival plaque samples which were collected at the end of the treatment, all cultures of patients in group (III) were negative for A. actionmycetemcomitans (table 9) these is agreement with the result of Gomes et $\mathrm{al}^{(22)}$, while in group (II) it was negative in three samples, on the other hand, three samples were positive but with reduced count compared with the first samples obtained before treatment. Considering group (I), cultures of subgingival plaque samples of two samples were negative for A. actionmycetem comitans. Four samples were positive but with reduced count of bacterium in three samples as compared with the first samples obtained before treatment, that is because patients in group (I) did not use any antibacterial agent or surgery that can affect the bacterium that allowing for re-colonization of the subgingival plaque after completion of the treatment. 
Collectively, the above mentioned data suggested a beneficial effect of adjunctive Propolis in the treatment of aggressive periodontitis by eradicating the main causative microorganism A. actionmycetemcomitans, preventing further bone loss by inhibition of osteoclasts maturation and performing its anti-inflammatory, anti-oxidant, immune-modulatory pharmacological properties. Moreover, better outcomes including more PPD reduction and more CAL gain were obtained with the adjunctive use of Propolis.

\section{CONCLUSION}

The findings of the present study have indicated that the sysytemic use of Propolis as an adjunct to open flap surgery has resulted in significant additional improvement in the clinical conditions of aggressive periodontitis patients when compared with SRP or surgical procedures. Moreover, this natural compound was highly effective as antibacterial agents against A. actinomycetemcomitans. Therefore, Propolis usage in the treatment of aggressive periodontitis is recommended rather than other systemic synthetic antibiotics.

Additional studies are needed to investigate whether the Propolis dosage used in this study is sufficient and will remain above the minimal inhibitory concentration levels for A. actinomycetemcomitans or increasing the dose, duration and frequency of intake could bring even better results in order to arrest ongoing periodontal breakdown in this disease.

\section{REFERENCES}

1. Janson, H.(2006): Studies on periodontitis and analyses of individuals at risk for periodontal diseases. Swedish Dental Journal 180,5-49.

2. Calas-Bennasar, Bousquet, P., jame,O., Orti. \& Gilbert, P.(2005): Clinical examination of periodontal diseases. EMC-Odontologie 1, 181-191.

3. Meng, H., Xu,L., Li.Qhao, y. (2007): Determination of host susceptibility in aggressive periodontitis . Periodontology $200043,133-159$.
4. Nibali, L., Donos, N., Brett,P.M., Parkar, M., Ellinas, T., Liorente,M. \& Griffiths,G.S. (2008a): A familial analysis of aggressive periodontitis - clinical and genetic finding. J. of Periodontal Reaseach 43, 627-634.

5. Tomofuji,t., Irie,K., Sanbe, T., Azuma, T., Ekuni, D., Tamaki, N., Yamamoto, T. \& Morita, M. (2009): Periodontitis and increase in circulation oxidative stress. Japanese Dental Science Review 45, 46-51.

6. Faveri, M., Mayer, M., Feres,M., de Figueiredo, L.C., Dewhirst, F. E. \& Paster, B.J. (2008): Micrrobiological diversity of generalized aggressive periodontitis by $16 \mathrm{~S}$, rRNA clonal analsis. Oral Microbiology and Immunology $23,112-118$.

7. Faveri,M., Figueiredo,L.C., Duarte, P.M., Mestnik, M. J., Mayer, M.P.A. \& Feres, M., (2009): Microbiological profile of untreated subjects with localized aggressive periodontitis. J. of Clinical Periodontology 36, 739 - 749.

8. Ximenz-Fyvie, L.A., Almaguer-Flores, A., Jacobo-Soto,V., Lara-Cordoba, M., Moreno-Borjas, J. \& Acantara-Maruri, E. (2006): Subgingival microbiota of periodontally untreated Mexican subjects with generalized aggressive periodontitis. J. of Clinical Periodontology 33, 869 - 877.

9. Andrian, E., grenier, D. \& Rouabhia, M. (2004): In vitro models of tissue penetration and destruction by Porphyromonas gingivalis. Infection and Immunology Journal, $72,4689-4698$.

10. Henderson, B., Nair,S.P., Ward, J.M., WILSON, M.(2003): Molecular Pathologenicity of the oral opportunistic pathogen actinobacillus actinomycetemcomitans. Annual Reviews in immunology 57, $29-55$.

11. Patural, L., Casalta, L. P., Habib, G., Nezri, M. \& Raoult, D. (2004): Actionbacillus actionmycetemcomitans endocardititis. Clinical Microbiology and Infection 10,98- 118.

12. Cairo do Amaral, R., Gomez, R. T., Rocha, W.M.S., Abreu S.L.R. \& Santo, V.R. (2006): Periodontitis treatment with Brazilian green propolis gel. Pharmacology online 3, 336-341.

13. Xajigeorgiou,C., Sakellari, D., Slini, A.\& Konstantinidis, A. (2006): Clinical and microbiological effects of different antimicrobials on generalized aggressive periodontitis. J. of Clinical Periodontology 33, 254 - 264.

14. Castaldo, S. \& Capasso, F.(2002): Propolis an old remedy used in modern medicine. Fitoterapia 83 (1), 51 - 56.

15. Bankova, V. S., Popova, M., Bogdanov, S. \& Sabatini, A. (2002): Chemical composition of European propolis: expected and unexcepted results. Zeitschrifit fur Natuforschung $57,530-533$. 
16. Kalogeropoulos, N., Konteles, S.J., Troullidou, E., Mourtzinos, I. \& Karathanos, V.T. (2009): Chemical composition, antioxidant activity and antimicrobial properties of propolis extracts from Greece and Cyprus. Food Chemistry $116,452-461$.

17. Sforcin, J.M., Oris, R. O. \& Bankova, V. (2005): Effect of Propolis, some isolated compounds and its source plant on antibody production. J. of Ethnopharmacology 98, 301 -305 .

18. Cushnie, T.P.T.,\& Lamb, A. J. (2005): Antimicrobial activity of flavonoids. A review. 2005. International Journal of Antimicrobial Agents, 26: 343 - 356.

19. Koru, O., Toksoy, F., Acikel, C.H., Tunca, Y.M., Baysallar, M., Guclu, A. U., Akca, E., Tuylu,A. O., Sorkun,K., Tanyuksel, M. \& Salih, B.(2007): In vitro antimicrobial activity of propolis samples from different geographical origins against certain oral pathogens. Anaerobe 13,140-145.

20. Boyanova, L., Kolarov, R., Gergova, G. \& Mitov, I. (2006): In vitro activity of Bulgarian propolis against 94 clinical isolates of anaerobic bacteria. Anaerobe 12, 173 - 177 .

21. Koo, H., Gomes, B.P.F.A., Rosalen, P.L., Ambrosano, G.M.B., Park, Y. K. \& Cury, j.A. (2000): In vitro antimicrobial activity of propolis and Arnica Montana against oral pathogens. Archives of Oral Biology 45,141 - 148 .

22. Gomes, R.T., Teixeira, K.I.R., Cortes, M. E., Santos, V.R. (2007): Antimicrobial activity of propolis adhesive formulation on different oral pathogens. Brazilian Journal of oral Science 6 (22), 1387 - 1391.

23. Nehal N. S., Shivaprasad B.M., Savita, S.(2014): Adjuvant in the Treatment of Chronic Periodontitis-A Clinicomicrobiologic Study. Journal of Clinical and Diagnostic research J Clin Diagn Res. Sep; 8(9): 41-44.

24. Coutinho A. (2012): Honeybee propolis extract in periodontal treatment. A clinical and microbiological study of propolis in periodontal treatment. Indian J Dent Res; 23:294.

25. AL-Dany A. A, Ramadan Y. AbuShahba, Marwa Mostafa, Mohamed I. Hashem (2014): Effect of honey in preventing gingivitis and dental caries in patients undergoing orthodontic treatment. Saudia Dental Journal sep; 9 (8): 455.

26. Samet, N., Laurent, C., Susarla, S. M. \& Rubinsteen, N.S. (2007): The effect of bee propolis on recurrent aphthous stomatitis: a pilot study. Clinical Oral Investigations 11, $143-147$.
27. Loe H.(1967) : The Gingival Index, the Plaque Index and the Retention index Systems. J. Periodtol ;38: 610.

28. Loe H., Silness J.(1963) : Periodontal disease in pregnancy I. Prevalence and severity. Acta Odontol Scand ; 21 : 533.

29. Carranza FA., Newman MG., Taki H., Klokkevold Rp. (2006) Clinical Periodontology. 10 ${ }^{\text {th }}$ ed. Philadelphia : WB Saunders and Co ; page $551-3$.

30. Slots, J. (1982): Selective Medium for Isolation of Actinobacillus actionmycetemcomitans. Journal of clinical microbiology April, 606 - 609.

31. Cruickshank, R., Duguid, J.P., Marmion, B. P. \& Swain, R. H. A. (1975): Tests for identification of bacteria. In: Textbook of medical microbiology. Churchill livingstone 1975.

32. Guerrero, A., Echeverria,J. J., tonetti, M. S.(2007): Incomplete adherence to an adjunctive systemic antibiotic regimen decreases clinical outcomes in generalized aggressive periodontitis patients: a pilot retrospective study. Journal of Clinical Periodontology 34, 897 - 902.

33. Haas, A.N., De Castro, G.D., Moreno, T., Susin, C., Albandar, J. M., Oppermann, R. V. \& Rosing, C. K.(2008): Azithromycin as an adjunctive treatment of aggressive periodontitis: 12-months randomized clinical trial. Journal of clinical periodontology 35, 696- 704 .

34. Trevilatto, P.C., Tramontina, V. A., Machado, M. A. N., Goncalves, R. B., Sallum, A. W., Line, S. R. B.(2002): Clinical, genetic and microbiological findings in a Brazilian family with aggressive periodontitis. Journal of Clinical Periodontology 29, 233 - 239.

35. Umeda, M., Takeuchi, Y., Noguchi, K., Huang, Y., Koshy, G. \& Ishikawa, I. (2004): Effects of nonsurgical periodontal therapy on the mocrobiota. Periodontology 2000 34, 98-120.

36. Haffajee, A. D., Cugini, M. A., Dibart, S., Smith, C., Kent, R.L. \& Socransky, S. S. (1997): The effect of SRP on the clinical and microbiological parameters of periodontal diseases. J. of Clinical Periodontology 24, 324 - 334.

37. Kleinfelder, J W., Muller, R. F., Lange, D. E. (2000): Fluoroquinolones in the treatment of Actionbacillus Actinomycetemcomitans- associated periodontitis. Journal of Periodontology 71, $202-208$.

38. Winkel, E. G., Van Winkelhoff, A.L., Timmermann, M. F., Van der Velden, U., Van Der Weijden, G. A. (2001): Amoxicillin plus metronidazole in the treatment of adult periodontitis patients. A double- blind placebo-controlled study. Journal of clinical periodontology 28, 296-305. 
39. Muller, H. P. \& Heinecke, A. (2004): Clinical effects of scaling and root planning in adults infected with Actinobacillus actinomycetemcomitans. Clinical Oral Investigations $8,63-69$.

40. Hang, H. C., \& Douglass, C. W.(2002): Meta-analysis of the effect of scaling and root planning, surgical treatment and antibiotic therapies on periodontal probing depth and attachment loss. Journal of Clinical Periodontology 29, 975-986.

41. Kim, T. S., Schenk, A., Lungeanu, D., Reitmeir, P. \& Eickholz, P. (2007): Nonsurgical and surgical periodontal therapy in single-rooted teeth. Clinical Oral Investigations $11,391-399$.
42. Serino, G., Rosling, B., Ramberg, P., Socransky, S.S. \& Lindhe, J. (2001): Initial outcome and long-term effect of surgical and non-surgical treatment of advanced periodontal disease. Journal of Clinical Periodontology $28,910-916$.

43. Marcucci, M. C.(1995): Propolis: Chemical composition, biological properities and therapeutic activity. Apidologie $26,83-99$.

44. Pileggi, R., Kathryn, A., Johnson, K., Zuo, J. \& Holliday, L. S. (2009): Propolis inhibits osteoclast maturation. Dental Traumatology 25, $584-588$. 